https://doi.org/10.22364/htqe.2019.06

\title{
WAYS TO IMPROVE THE COMPETITIVENESS OF HIGHER EDUCATION PROGRAMS
}

\author{
Elena N. Letiagina \\ Lobachevsky State University of Nizhni Novgorod, Russia \\ Julia A. Grinevich \\ Lobachevsky State University of Nizhni Novgorod, Russia \\ Alexander V. Gutko \\ Lobachevsky State University of Nizhni Novgorod, Russia
}

\begin{abstract}
The article describes the main trends in the development of higher education in the world. The aim of this work, as defined by the authors, is to develop the main directions for increasing the competitiveness of educational programs of higher education taking into account modern trends. An analysis of the possibilities for increasing the competitiveness of higher education programs implemented by universities is presented. The proposed ways to improve the competitiveness of educational programs include increased involvement in the processes of international cooperation in the field of education, the internationalization of the educational process, the creation of modern training programs aimed at obtaining several professions in related fields of knowledge, wider involvement of professionals from specialized organizations in the teaching process. Particular attention is given to the factors and measures in the framework of internationalization that directly affect the competitiveness of educational programs.
\end{abstract}

Keywords: competitiveness, competitiveness of educational programs, educational programs, higher education, internationalization of education, professional standards.

\section{Introduction}

Over the past several years, higher education institutions have been faced with global changes. Bologna reforms have led to a significant modernization of the education system in European universities. In addition, the changing 
conditions of political and economic, social and cultural systems require modern universities to apply proactive strategies aimed at modernizing educational programs and developing their infrastructure capabilities.

Further large-scale changes in education are inevitable in the coming years. Education becomes continuous, universal, person-oriented, represented by a variety of different forms.

The transformation of education is seen as a new opportunity for business and economic growth, an instrument of influence in the global market (Schleicher, 2017). The state and society can support or block these opportunities.

\section{Results \& Discussion}

The main modern trends in the development of higher education can be identified as follows (Neubauer, 2012):

- improving the quality of education and creativity of universities (Gogoleva, Balgimbaeva, 2012);

- adjusting educational programs to the needs of society, universities and business;

- taking into account technological, financial and environmental standards;

- designing the educational process in the context of accelerating changes in industry, economy and society, due to the development of technology and the growing complexity of global markets and management systems;

- developing and strengthening labor market orientation of bachelor's programs;

- developing an effective system of quality assurance in universities, fostering the development of an institutional culture of quality;

- modern approaches to the design of accreditation systems, independent certification systems;

- lifelong education to support human development throughout life;

- obsolescence of many traditional professions in connection with the introduction of artificial intelligence, robotics, automated control systems, the emergence of new professions;

- the impact of global rankings on research in the field of higher education and the production of knowledge;

- creation of global educational platforms, the emergence of "universities for a billion";

- personalization of learning paths;

- the aging of the population, the growth of the middle class and the growth of the quality of health care lead to the emergence of a mass and 
growing class of socially, physically and mentally active people over 60 and, as a consequence, the emergence of Universities of the Third Age; - development of cognitive technologies, etc.

At the same time, in a significant number of educational institutions, the main factor of their existence in the market is a high level of competitiveness. Universities face daily competition for new talented students.

The educational institution becomes a more significant element of the market system, forming public consciousness, imparting knowledge and skills, while being a seller of educational services and a buyer of highly skilled labor.

Given the increasing requirements to the quality of education and the need to introduce new learning technologies, as well as dynamic changes in the conditions of functioning and increased competition in the market of educational services, universities not only need to have a highly qualified teaching staff, modern equipment and infrastructure, to use innovative teaching methods, but also must offer competitive individual educational programs. Much attention should be also paid to the reputation of the University and its place in various international rankings. At the same time, the educational institution should take into account the needs of the labor market and shape its educational programs depending on the changing requirements of potential employers.

Improving the competitiveness of universities and their educational programs can be achieved by a wider participation in the processes of international cooperation in the field of education. Internationalization of educational programs is a fundamental factor in the preparation of highly qualified specialists who are able to work in a multinational environment and meet the requirements of the international labor market.

Internationalization of education will make it possible to achieve the universality of acquired knowledge and skills (Grinevich, Kemaev, Kemaeva, 2011), to focus on international trends and requirements of the labor market, to increase innovation in higher education, to promote the development of science through joint research (Smith, 2012, Fokina, 2014).

By establishing joint laboratories and conducting joint research, more opportunities will be provided to expand grant support for research, to increase publication activity in international publications and to hold joint international conferences.

Another modern approach to attracting students is to create modern training programs aimed at obtaining several professions in related fields of knowledge by introducing a modular principle of training.

The development of educational programs can be based on the method of functional analysis, involving the "inventory" of professional standards and their labor functions in the relevant field of professional activity. 
By clarifying with employers the understanding of the content of work types and work functions that are necessary to ensure their effectiveness, it will be possible to determine the content of training modules. Each module may include the training in several disciplines, and the acquired knowledge and skills will be further consolidated during students' internships. Thus, in the course of their training, students will have the opportunity to gain skills in several professions. This will improve the adaptability and ensure graduates' success in the labor market.

The development of educational programs in foreign languages in various areas of training will improve the academic mobility of students, the recognition of the University, and will contribute to the development of exchange education programs and double degree programs; it will also help to increase the number of partner universities. Increased mobility will improve the visibility of the University and its educational programs in other countries, it will also expand the general cultural and professional competence of teachers and students, will help to strengthen the position of the University in the international market of educational services and create its favorable image (Gorylev, Avralev, Kamynina, 2017). Professional development of teaching staff members at foreign universities, the involvement of specialists from foreign educational institutions and companies will provide an opportunity to introduce relevant knowledge and skills in the educational process. Exchange of faculty members who teach their courses in a foreign language will contribute to enhancing the exchange of knowledge and experience, it will also raise the prestige of the educational program as a whole (Tsvigun, 2015).

\section{Conclusion}

We describe the results of this research the main trends in the development of higher education in the world, which show directions for increasing the competitiveness of educational programs of higher education.

We believe that it is possible to carry out joint research, international activities, establishing joint laboratories, the creation of modern training programs aimed at obtaining several professions in related fields of knowledge, network programs, etc., that will be a productive form of interaction between universities, which ultimately give a synergistic effect. In order to improve the organization of training and provide the economy with competitive personnel, it is necessary to involve in the training process not only regular faculty members, but also practitioners with considerable experience in respective professional fields. This approach will contribute to the convergence of theoretical knowledge and practical activities of students. These are important findings in the understanding of the an 
analysis of the possibilities for increasing the competitiveness of higher education programs implemented by universities.

These basic findings are consistent with research showing that education becomes continuous, universal, person-oriented and the transformation of education is an instrument of influence in the global market, business and economic growth.

Increasing the attractiveness of the University for students requires an integrated approach to the study and development of appropriate recruitment strategies. Heads of higher education institutions should know and understand the determinants that influence the decisions on student enrollment. Future research should further develop and confirm these initial findings and should conduct to identify the motivation of students in choosing a higher education institution.

\section{References}

Czvigun I. V. The Role of international activities in the formation of the University brand: the experience of the faculty of world economy and public administration of the Baikal state University of Economics and law // proceedings of the Baikal state University, 2015, Vol. 25, № 2, P. 239-247.

Gorylev A. I., Avralev N. V., Kamynina N. R. Joint programs as a tool of building european higher education area // Espacios, Vol 38, (№ 25), 2017, P. 13.

Fokina V. V. Internationalization of higher education as a factor of competitiveness of modern higher educational institutions / / Management consulting, 2014, № 11 (71), P. 108-112.

Gogoleva T. N., Balgimbaeva A. T. the Competitiveness of educational programs as a way to improve efficiency in the field of educational services //Economics of education, 2013, № 1, S. 61-63.

Grinevich Yu. A., Kemaev K. V., Kemaeva M. V. State policy of Russia in the field of international education as a mechanism of development of the real sector of the economy// Bulletin of Nizhny Novgorod University. N. So. Lobachevsky, 2011, № 5-2, P. 55-60.

Lifelong Learning Policies and Strategies, UNESCO Institute for Lifelong Learning, 2014.

Neubauer, D. Ten challenges of globalization for quality higher education and quality assurance, EWC, www.eastwestcenter.org, 2012.

Schleicher A. How to surf the new wave of globalization. 2017, 4 May. URL: http:// oecdeducationtoday.blogspot.ru/2017/05/how-tosurf-new-wave-of-globalisation.html

Smith D. The World from Berlin: German Universities 'Share Blame' for Problems, in Spiegel Online International, 15 August 2012.

Titova N. G., Smirnova T. V. Interactive methods of teaching in the teaching of economic disciplines / / Innovative methods of teaching in higher school collection of articles on the results of the methodical conference of UNN. National research Nizhny Novgorod state University. N. So. Lobachevsky, 2016, P. 226-229. 